http://jmscr.igmpublication.org/home/ ISSN (e)-2347-176x ISSN (p) 2455-0450

crossref DOI: https://dx.doi.org/10.18535/jmscr/v8i3.124

\title{
Efficacy of autologous platelet rich fibrin in chronic non healing lower limb ulcers
}

\author{
Authors \\ Dr Sai Sudha Alaparthi ${ }^{1}$, Dr M. Mallikarjuna Reddy ${ }^{2 *}$, Dr Madhavi Polu ${ }^{3}$ \\ General Surgery Department, NRI General Hospital, Mangalagiri, Guntur District, \\ Andhra Pradesh, 522503, India \\ *Corresponding Author \\ Dr M. Mallikarjuna Reddy
}

\begin{abstract}
Non healing ulcer is a chronic condition and one of the cause of disability. Platelet rich fibrin (PRF) is one of the newer modalities and it contains fibroblast growth factor, vascular endothelial growth factor and platelet derived growth factor which enhances wound healing. It is a prospective study to demonstrate the efficacy of autologous platelet rich fibrin in chronic non healing lower limb ulcers.

Keywords: Platelet rich fibrin $(P R F)$.
\end{abstract}

\section{Introduction}

Chronic non healing ulcer is defined as "loss of skin and subcutaneous tissue on leg or foot which takes more than 6 weeks to heal". The prevalence of leg ulcers is documented to vary between $0.18 \%-1 \%{ }^{[1]}$. Major causes of ulcer are diabetic, venous, arterial, neuropathic, traumatic. Chronic wounds are characterised by long inflammatory phase that hinders regenerative wound healing. Standard treatment algorithm includes complete patient and wound assessment, history, physical examination, and variety of diagnostic test that determine the need for infection control, debridement. The treatment is often difficult and is generally associated with high recurrence rates ${ }^{[2,3,4]}$. The aim of the study is to determine the efficacy of PRF in chronic non healing lower limb ulcers.

\section{Methods}

This is a prospective study to study the efficacy of PRF in epithelialization and wound reduction in chronic wounds. 32 cases were compiled in this study which was done in NRI General hospital.

Inclusion Criteria: Age group of 18 to 80 years with long standing non healing ulcers, ulcers of more than 6 week duration and patient $\mathrm{Hb} \%>10 \mathrm{gm} / \mathrm{dl}$.

Exclusion Criteria: Patients with known or suspected osteomyelitis, presence of cellulitis, peripheral vascular disease (inadequate perfusion), ischemia, gangrene and patient not willing for study. Preparation of Material: Under strict aseptic conditions $20 \mathrm{ml}$ of venous blood drawn and added to red coloured vacutainer which contains clot activator. In first spin the tube is centrifuged at 5000rpm for 15 min to separate red blood cells from plasma. After $1^{\text {st }}$ spin 3 layers appeared. Bottom of the tube contains Red blood cells, middle layer 


\section{JMSCR Vol||08||Issue||03||Page 735-738||March}

contains buffy coat, which contains platelets and leukocytes, upper phase contains clear solution of platelet poor plasma. Again it is centrifuged at 2000rpm for 5-10 $\mathrm{min}^{[5]}$.

Dressing Technique: Ulcer cleaned with normal saline. PRF prepared from patient blood and injected into the edge of the ulcer and fibrin plug is placed directly on the ulcer. The dressing is kept for a period of 3-4 days depending on the wound.

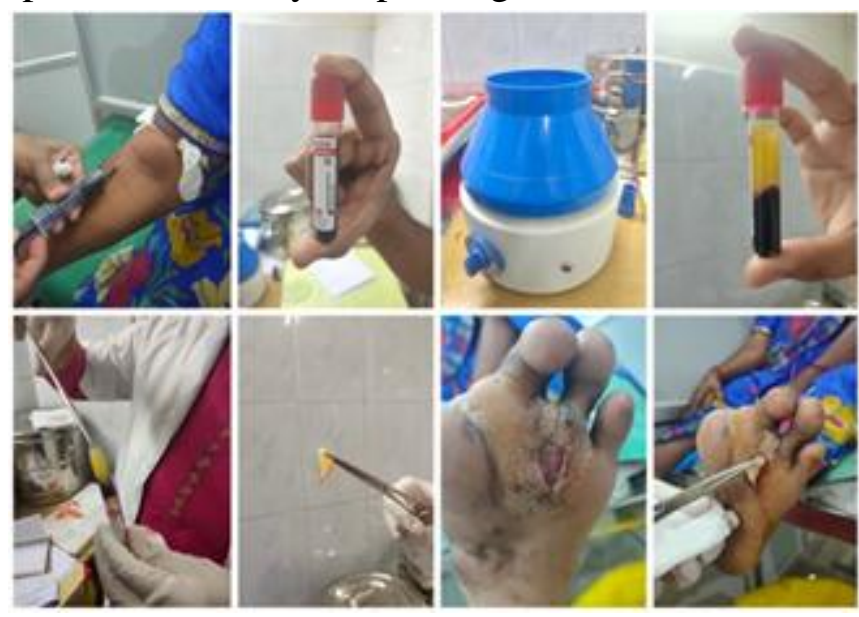

This is repeated every week for a period of 6 weeks.

\section{Results}

Out of 32, 12 patients were excluded in the study. Out of 12 patients 4 were anaemic, 3 had proven osteomyelitis, 1 had gangrene of toe, 2 had cellulitis of that limb, 1 patient not willing for the study, 1 had peripheral vascular disease.

Age distribution and aetiology of ulcers

\begin{tabular}{|l|c|c|c|}
\hline Age & No.of cases & Aetiology & No.of cases \\
\hline $18-35$ yrs & 3 & Diabetic & 7 \\
\hline $36-50$ yrs & 11 & Traumatic & 2 \\
\hline $51-65$ yrs & 5 & Trophic & 9 \\
\hline $66-80$ yrs & 1 & Venous & 2 \\
\hline
\end{tabular}

\begin{tabular}{|l|l|c|c|c|c|c|c|c|}
\hline & $\begin{array}{l}\text { Location } \\
\text { of ulcer }\end{array}$ & $\begin{array}{c}\text { Are } \\
\mathrm{a}\end{array}$ & $\begin{array}{c}1^{\text {st }} \mathrm{pr} \\
\mathrm{f}\end{array}$ & $\begin{array}{c}2^{\text {nd }} \mathrm{p} \\
\mathrm{rf}\end{array}$ & $\begin{array}{c}3^{\text {rd }} \mathrm{p} \\
\mathrm{rf}\end{array}$ & $\begin{array}{c}4^{\text {th }} \mathrm{p} \\
\mathrm{rf}\end{array}$ & $\begin{array}{c}5^{\text {th }} \mathrm{p} \\
\text { rf }\end{array}$ & $\begin{array}{c}6^{\text {th }} \\
\text { rf }\end{array}$ \\
\hline 1. & $\begin{array}{l}\text { Lateral } \\
\text { malleolus } \\
\text { of rt foot }\end{array}$ & $\begin{array}{c}15 \mathrm{c} \\
\mathrm{m}\end{array}$ & 15 & 14 & 13 & 11 & 9 & 7.5 \\
\hline 2. & $\begin{array}{l}\text { Lateral } \\
\text { malleolus } \\
\text { of lt foot }\end{array}$ & $4 \mathrm{~cm}$ & 4 & 3.5 & 3.5 & 3 & 2 & 1.5 \\
\hline 3. & Rt heel & $3 \mathrm{~cm}$ & 2.5 & 2 & 2 & 1.5 & 1 & 0.5 \\
\hline 4. & $\begin{array}{l}\text { Base of } \\
2^{\text {nd }} \\
\text { metatarsal } \\
\text { of lt foot }\end{array}$ & $2 \mathrm{~cm}$ & 1 & 0.5 & & & & \\
\hline 5. & $\begin{array}{l}\text { Plantar } \\
\text { aspect of }\end{array}$ & $\begin{array}{l}20 \mathrm{c} \\
\mathrm{m}\end{array}$ & 19 & 18.5 & 17 & 16 & 14.5 & 13 \\
\hline
\end{tabular}

\begin{tabular}{|c|c|c|c|c|c|c|c|c|}
\hline & $\mathrm{rt}$ foot & & & & & & & \\
\hline 6. & $\begin{array}{l}\text { Sole of lt } \\
\text { foot }\end{array}$ & $5 \mathrm{~cm}$ & 4 & 3.5 & 2.5 & 2 & 0.5 & \\
\hline 7. & $\begin{array}{l}\text { Sole of lt } \\
\text { foot }\end{array}$ & $4 \mathrm{~cm}$ & 3 & 3 & 2.5 & 2 & 1 & 0.5 \\
\hline 8. & $\begin{array}{l}\text { Sole of } \mathrm{rt} \\
\text { foot }\end{array}$ & $3 \mathrm{~cm}$ & 2.5 & 1.5 & 1 & 0.5 & & \\
\hline 9. & $\begin{array}{l}\text { Sole of lt } \\
\text { foot }\end{array}$ & $2 \mathrm{~cm}$ & 1.5 & 0.5 & & & & \\
\hline 10 & $\begin{array}{l}\text { Sole of } \\
\text { rtfoot }\end{array}$ & $4 \mathrm{~cm}$ & 2.5 & 2 & 1 & 0.5 & & \\
\hline 11 & $\begin{array}{l}\text { Heel of lt } \\
\text { foot }\end{array}$ & $2 \mathrm{~cm}$ & 2 & 1.5 & 1.5 & 1.5 & 1 & 1 \\
\hline 12 & $\begin{array}{ll}\text { Rt } & \text { great } \\
\text { toe }\end{array}$ & $2 \mathrm{~cm}$ & 1.5 & 1 & 0.5 & & & \\
\hline 13 & $\begin{array}{l}\text { Base of } \\
5^{\text {th }} \text { metatar } \\
\text { sal }\end{array}$ & $3 \mathrm{~cm}$ & 2 & 1.5 & 0.5 & & & \\
\hline 14 & $\begin{array}{l}\text { Dorsum of } \\
\text { rt foot }\end{array}$ & $5 \mathrm{~cm}$ & 4.5 & 4 & 3 & 2.5 & 2 & 1 \\
\hline 15 & $\begin{array}{l}\text { Medial } \\
\text { malleolus } \\
\text { of lt foot }\end{array}$ & $2 \mathrm{~cm}$ & 1.5 & 0.5 & & & & \\
\hline 16 & $\begin{array}{l}\text { Dorsum of } \\
\text { lt foot }\end{array}$ & $3 \mathrm{~cm}$ & 2 & 1.5 & 1.5 & 1 & 1 & 0.5 \\
\hline 17 & $\begin{array}{l}\text { Stump of } \\
\text { lt BKA }\end{array}$ & $4 \mathrm{~cm}$ & 4 & 3.5 & 2.5 & 2 & 1.5 & 1 \\
\hline 18 & $\begin{array}{l}\text { Medial } \\
\text { aspect of } \\
\text { lt foot }\end{array}$ & $6 \mathrm{~cm}$ & 5.5 & 5 & 4 & 3.5 & 2.5 & 1 \\
\hline 19 & $\begin{array}{l}\text { Heel of } \mathrm{rt} \\
\text { foot }\end{array}$ & $4 \mathrm{~cm}$ & 3.5 & 2.5 & 2.5 & 2 & 2 & 1.5 \\
\hline $\begin{array}{l}20 \\
\cdot\end{array}$ & $\begin{array}{l}\text { Lateral } \\
\text { aspect of } \\
\mathrm{rt} \text { foot }\end{array}$ & $5 \mathrm{~cm}$ & 5 & 4.5 & 3.5 & 3 & 2 & 1 \\
\hline
\end{tabular}
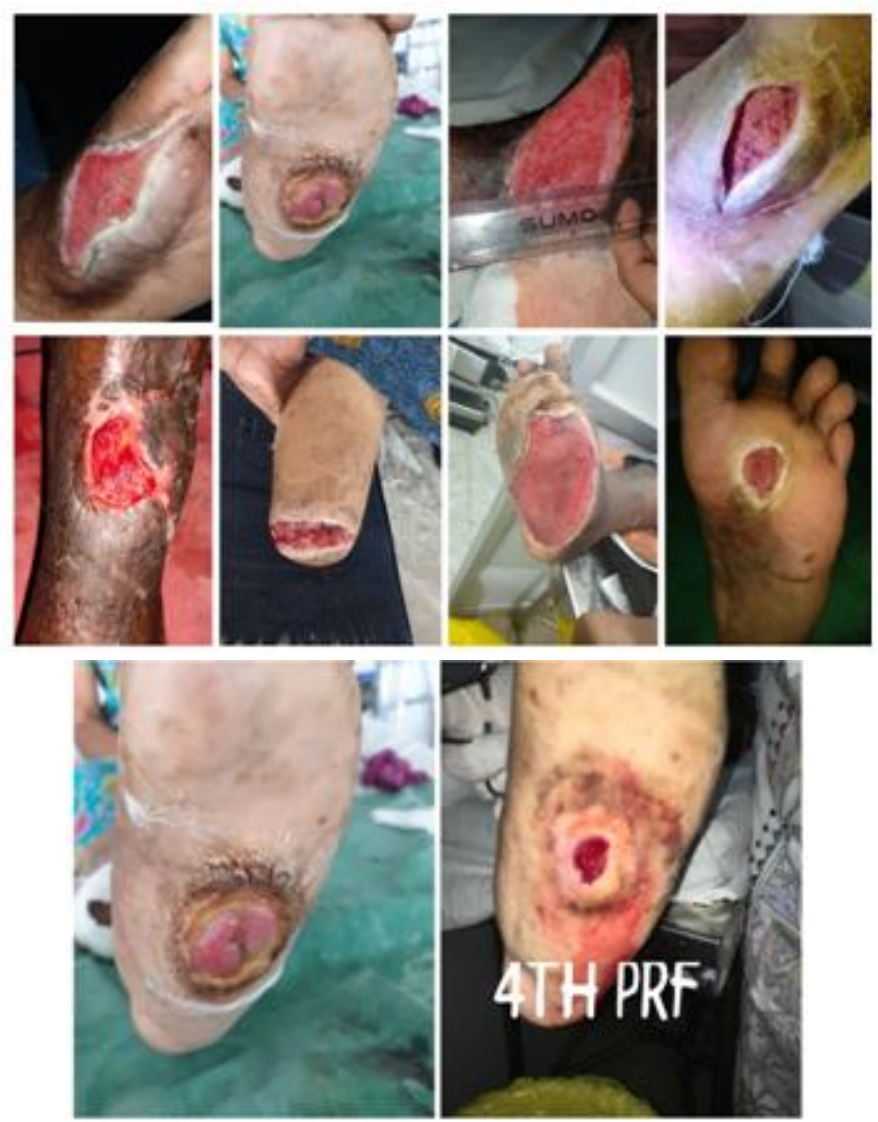


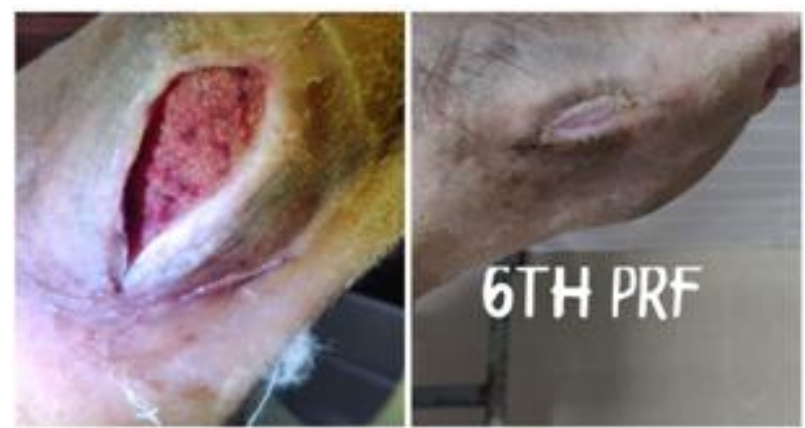

\section{Discussion}

Plantar ulcer is the most common disability. By shortening the wound healing phase the quality of life of these patients can be improved. Platelet rich fibrin (PRF) is an autologous platelet and leucocyte rich fibrin material and is an important advancement in regenerative medicine. It forms an organised network where the platelets and leukocytes are concentrated leading to sustained release of various growth factors resulting wound healing. Hence it can be used in the treatment of venous ulcers ${ }^{[6]}$.

PRF was first developed by Choukroun et al. ${ }^{[7]}$ in France for use in oral and maxillofacial surgery.

PRF belongs to new generation of platelet concentrates with simplified preparation. This technique neither requires anticoagulant nor bovine thrombin (nor any other gelling agent). It is just centrifuged blood without any addition. The absence of anticoagulant implies the activation in few minutes. Fibrinogen is initially concentrated in higher part of the tube, before thrombin transforms it into fibrin clot, which is concentrated in middle of the tube, just between the red corpuscles at the bottom and acellular plasma at top. Platelets are theoretically trapped in fibrin meshes.

A study conducted by Margolis et al. Which included 26,599 patients, concluded that patients who are treated with products derived from platelets, tend to heal faster than patients who are treated without the products derived from platelets. He also concluded that even though the ulcers that were treated with these derivatives were bigger and deeper than the other groups, these showed better improvement at the end of 12 weeks ${ }^{[8]}$.

In another study, Anita et al. Showed that healing increased significantly with the help of PRF. She also concluded that it not only helps in supplying the required GF's but also by forming fibrin matrix which helps in cell migration, it also helps in neovascularization ${ }^{[9]}$.

\section{Mechanism of action of platelet rich fibrin}

It functions as a tissue sealant and platelets initiate the wound repair by releasing locally acting growth factor via alpha granules degranulation.

Alpha granules of platelet contains platelet derived growth factor, transforming growth factor, interleukin-1, platelet derived angiogenesis factor, epithelial cell growth factor, insulin like growth factor, osteocalcin, osteonectin, fibrinogen factor and thrombospondin-1.

These growth factors help in healing by attracting undifferentiated cells in Newley formed matrix and triggering cell division. PRF may suppress cytokines release and limit inflammation, interacting with macrophages to improve tissue healing and regeneration and promote new capillary growth and accelerate epithelialization in chronic wounds $^{[10]}$.

\section{Conclusion}

We would like to conclude that the use of PRF dressings as an adjuvant therapy in treatment of chronic non healing ulcer of lower limbs shows great potential to achieve complete closure of ulcers and can be successfully be used as a routine procedure in the management. Out of 20 patients 8 patients has completely healed. Out of 8 patients 6 patients had ulcers over sole which healed completely. This procedure is simple, patient friendly, cost effective, painless and can be performed as an outpatient procedure.

\section{References}

1. Anderson I. Aetiology, assessment and management of leg ulcers. Wound Essent. 2006; 1:20-36.

2. Bergqvist D, Lindholm C, Nelzen O. Chronic leg ulcers: The impact of venous disease. J Vascsurg. 1999; 29:752-5. 
3. Evans CJ, Fowler's FG, Ruckley CV, Lee AJ. Prevalence of varicose veins and chronic insufficiency in men and women in the general population: Edinburgh Vein Study. J Epidemiol Community Health. 1999; 53:149-53.

4. Mayer W, Jochmann W, Partsch H. Varicose ulcer: healing in conservative therapy. A prospective study. Wein Med Wochenschr. 1994; 144:250-2.

5. Sampson S, Gerhardt M, Mandelbaum B. Injection grafts for musculoskeletal injuries: a review. Curr Rev Musculoskelet Med. 2008;1:165-74.

6. O'Connell SM, Impeduglia T, Hessler K, Wang XJ, Carroll RJ, Dardik H. Autologous platelet rich fibrin matrix as a stimulator of healing chronic lower extremity ulcers. Wound Repair Regen. 2006;14:A76.

7. Choukroun J, Adda F, Schoeffler C, Vervelle A. An opportunity in perioimplantology(in French): The PRF. Implantodontine. 2001; 42;55-62.

8. Margolis DJ, Kantor J, Santana J, Strom BL, Berlin JA. Effectiveness of platelet releasable for the treatment of diabetic neuropathic foot ulcers. Diabetic Care. 2001;24:483-8.

9. Anita E, Sanchez M, Nurden AT, Zalduendo $M$, de la Fuente $M$, Orive $G$, et al. Autologous fibrin matrices: A potential source of biological mediators that modulate tendon cell activities. J Biomed Mater Res A. 2006;77:285-93.

10. Knighton DR, Doucette M, Fiegel VD, Ciresi K, Butler EL, Austin L. The use of platelet derived wound healing formula in human clinical trials. Prog Clinton Biol Res. 1988; 266:319-29. 